\title{
article
}

\section{Job precariousness among lawyers in Spain}

\author{
Sandra Obiol-Francés, sandra.obiol@uv.es \\ Antonio Santos-Ortega, Juan.A.Santos@uv.es \\ David Muñoz-Rodríguez, francisco.d.munoz@uv.es \\ University of València, Spain
}

This article stems from an interest in discovering how working conditions have changed in qualified professions in Spain, concentrating on lawyers. Using a qualitative method, we have found significant sources of precariousness that are transforming the profession's ways. Throughout this article, light has been cast on the connections between the changing professional model of the lawyer's job over the past three decades and the emergence of precarious situations. Our findings highlight that there has been a transformation in the occupation of lawyers in Spain: income and professional careers are marked by extreme uncertainty, raising psychosocial risks.

Key words lawyers $\cdot$ precariousness $\cdot$ self-employment $\cdot$ careers $\cdot$ entrepreneur

To cite this article: Obiol-Francés, S., Santos-Ortega, A. and Muñoz-Rodríguez, D. (2019)

Job precariousness among lawyers in Spain, Journal of Poverty and Social Justice,

DOI: 10.1332/175982718X15451304489459

\section{Introduction}

Although the financial crisis that began in 2007 has been associated with the more vulnerable salary ranges, in fact it brought a complex series of effects that ended up also having repercussions in employment sectors with greater qualifications and status in the job market. For those employed in such sectors, the situation brought with it cuts, legislative changes and harsh economic adjustment that ended up affecting their job activity. In addition to these circumstances, there has been an effect felt from deeper transformations related to globalisation and information technology, which have been having consequences since the end of the 1990s on the structure, functions and content of the liberal professions that are the subject of this article.

The main purpose of the research from which this article stems is to analyse the situation of these liberal professional groups in the context of the sub-prime crisis, and even in the context of the arguable middle-class crisis (Atkinson and Brandolini, 2013; Streeck, 2013; Hernández, 2014; Chauvel and Hartung, 2016; Milanovic, 2016). To do so, we have chosen three professional profiles: lawyers, architects and journalists, who represent occupations that are very much identified with the new salaried middle classes with further education as well as with the old 
middle classes with independent jobs in their own offices. These groups experienced times of stability and even splendour before the crisis because of the vitality that economic activity generated in their sectors in Spain. In this article, we focus on the profile of lawyers since in this country they are undergoing a change in terms of access to their profession and the work they subsequently do within it. On the one hand, their average profile is now younger and more female, which has made their position in the structure of employment more fragile. On the other, there is strong demand for the profession to modernise in practice; in other words, there is now greater focus on activities that until now had been marginal ones such as commercial tasks and their presence in the social networks. We have also intended to focus on the independent work done by these liberal professionals, whose activity dropped off as a result of the economic crisis, intensifying the process of change in the profession that has led to offices closing, a shrinkage in their income and client portfolio, and to having to reinvent themselves professionally. Furthermore, as we shall see further on, the Spanish system of social protection for self-employed people is clearly insufficient, which places them in a particularly weak position. While not denying that the lawyer's profession still retains considerable symbolic and political power, over the last 20 years it has been caught in the thick of a changing panorama (Susskind, 2013). The expectations on entering the profession in terms of status and economic stability are no longer so certain.

We consider that it is more useful for sociological analysis to study the concept of job precariousness by addressing its many dimensions. Approaches that construct a complex view of job precariousness take into account the conditions of employment (fundamentally the types of contract and personal situations); the working conditions (shifts, timetables, workload, potential occupational hazards); the wage conditions and finally the different conditions necessary for accessing social coverage that a precarious post may entail (Cano, 1998; Santos and Muñoz, 2017).

More recently, different specialists in this field (Lazzarato, 2013; Laval and Dardot, 2013) have pointed out that precariousness is not merely a problem of bad conditions in the job market; it also ends up forming part of individuals' biographies, sowing uncertainty in their lives and going beyond matters of work. Indeed, uncertainty ends up affecting the timing for planning one's life. One has to plan work and life with a just-in-time approach, or else postpone or anticipate events in life with little information and a lot of uncertainty. Precariousness thus takes root in the most intimate sphere of ontological precariousness, where the subjects ponder their future and their very existence (Butler, 2009; Lorey, 2014).

We have detected these different facets, from aspects more related to the job market (processes of work intensification, lack of continuity in demand for their services, and their insufficient earnings) to those that go beyond the sphere of work and become a heavy uncertainty as regards life in those little offices.

The aim of this article is to give a general idea of the true situation being experienced by the lawyers interviewed, attempting to identify their main sources of precariousness - such as working conditions, income and career paths - as well as their responses to their worsening standard of living. In the first section, we give the theoretical context to transformations in jobs and life that liberal professions are experiencing generally and lawyers specifically. In the second section, we concentrate on analysing the increasing precariousness experienced by more vulnerable groups of lawyers, as recorded in the interviews we have carried out. Finally, there is 
a conclusions section where the most noteworthy aspects of these processes of precariousness are underline.

\section{Crisis and changes in society and labour in independent liberal professions: the case of lawyers}

In the debate on the decline of the middle classes, numerous arguments have been bandied about in the social sciences (Butler and Savage, 1995; Frank, 2007; Castel, 2010; Fourquet et al, 2013; Damon, 2014; Castells, 2015). These authors have emphasised the transformations that were set during the 1980s in the context of the social and economic restructuring that followed the 1973 crisis. The profound difficulties of the capitalism were tackled in the sphere of labour with employment deregulation, privatisations, globalisation, outsourcing and relocations that had an impact on class structure. In the political sphere, the progressive reformulation of the role of the state by applying the guidelines of New Public Management brought about readjustments and changes in healthcare, social services and education. These sectors, which drive the middle classes, have seen their progress slowed up or halted compared to previous decades, suffering from the processes of privatisation, cutbacks and commodification that we are still seeing today (Jessop, 2016). In social discourses, the political neoliberal hegemony imposed an ideological takeover that gradually infused social relations with new values. The idea of stability was replaced by the ideas of change, flexibility and fluidity in the context of the rise of neoliberalism (Sennett, 1998; Bauman, 2006).

It is difficult to tell if we have been witnessing the end of the middle class over the last three decades, but according to the aforementioned authors there is no doubt that there are many factors that help to spread this idea and the social points of reference of the middle class are being altered (Therborn, 2015). Our research is not ambitious enough to delve deeply into this matter, but to specifically analyse the professional changes among lawyers in the context of the aforementioned atmosphere of crisis and changes in social structure.

In his analysis focusing on the labour decline of the middle classes, Sergio Bologna (2006) underlines the importance of the progressive dismantling of public employment, which had been the main job supplier for the intermediate strata. The second factor he indicates is the worsening employment for intermediate-level occupations which, subject to the new rules of business management, have suffered an intensification in their work with no accompanying rise in salaries. These new rules have widened the gap between high-level executives and other employees, creating a chasm between the upper and middle classes. Together with these changes in work for employees, Bologna also sees transformations that are very relevant in the field of independent, self-employed and small business work. Added to the first generation of self-employed workers (liberal professionals, small businesses and small farms) characteristic of the middle classes' golden age in the era of Ford, there is now the second generation of self-employed work (Bologna and Fumagalli, 1997). This type of work is made up of cognitive workers and workers in the sector of services for people and it was given a great boost in the 1990s with the new economy. In 2000, however, following the crisis of technological companies and the subsequent unstable situation, they came under pressure and a worsening material situation. The crisis of 2007 had a serious 
effect on these sectors, which have become increasingly fragile and dependent on credit systems that are frozen today.

Bologna interprets that it is not only the growth in atypical work and the precariousness of labour that defines this conception, but that we are witnessing an expansion of a new legal nature of labour relationships. The fundamental characteristic is that these relationships are gradually coming to be seen as a business one between two entities, both of which are understood to be 'companies'. The worker is conceived as an external supplier, a company that provides a service to other companies and receives an income for it. It is not a salary to reproduce the effort of work, but a remuneration in exchange for providing a service. This change in the conceptual background compared to Fordist capitalism implies a profound transformation in labour relationships and class relationships. In the new, post-Fordist model, the idea is spreading that workers must take charge of themselves and be responsible for recycling themselves and their ongoing education (and cover costs that used to be included in the Fordist labour relationship). The new model of labour relationship burdens the workers themselves with the risks and eventualities of economic and production situations that used to be part of the company's role.

This new model of labour relationships is gradually spreading and although it affects all workers, it has repercussions especially in the world of self-employed workers and small companies. The shift of risk creates uncertainty among these workers as regards the future, as well as insecurity and excessive work that seeps into personal and family spheres. These processes can be seen clearly in the interviews we have carried out that we will look at later.

\section{The new profiles of legal professions and the rise of the lawyer-businessperson}

The most widely renowned specialists in this matter have looked at how the aforementioned changes and processes in the world of lawyers have shown themselves (Susskind, 2008; 2013). Although Susskind's observations are intended for the English-speaking world, his conclusions and predictions can be extended to any other place, opening up debates on an international scale. Furthermore, his arguments are based on the idea of professional and technological changes occurring around the world, beyond national borders, which have affected legal professions as a whole since the 1980s. The changes he describes fundamentally affect the new technological procedures in the judiciary and courts, the new systems for education and e-learning, the outsourcing of legal proceedings and the economic adjustments forced upon them by the crisis situation. These changes entail and impose a restructuring of the legal sector. Based on them, Susskind calls on professionals to address them by detecting their distinctive skills and talents and by taking action to bring themselves up to date technologically, standardise processes, take a different approach to remuneration systems and adapt to the trends underway in terms of deregulation of the professional sector. All of these proposals spell the end of the traditional model of the lawyer. Gradually, the market will no longer demand the obsolete, costly services of lawyers based on guidance, consultancy, research, drafting documents and solving problems. All such functions can be fragmented, specialising tasks and seeking profitable, cheaper ways to provide legal services largely based on technological systems that are gradually spreading. 
As a result of these structural changes, lawyers are driven to take responsibility for their own career and to take the initiative to maintain their professional skills due to the fear of becoming obsolete and so left behind in terms of skills. The classic lawyer's tasks (drafting contracts, wills and so on) are becoming mere commodities with the advance of technology. In fact, rapid progress is being seen in online legal platforms such as Legal Zoom in the United States and Legalitas and Legal in Spain, since they provide services at very low prices thanks to lower costs and the potentially high demand due to the ease of access and marketing strategies.

This situation represents a crisis for the traditional lawyer in Spain. And it is not a circumstantial crisis. In the times just before the sub-prime crisis, a shift in the concept of lawyers and their professional structure had already been seen in Spain. This shift can be summed up with the idea of a change from a model of the lawyers' profession based on lawyers' offices to one based on legal services companies. Ideas such as the legal entrepreneur (Sánchez Fernández, 2014), New Law (Böck, 2015) and Legal Project Management (Garrido Navarro, 2015) establish a modernising fusion of the fields of legal and economic knowledge, and paint a negative picture of the previous model. They see that model as antiquated, technologically obsolete, unsuitably managed and with a lack of commercial know-how, language skills, commitment and professional concern, while being individualistic and isolated (Moreno-Meyerhoff, 2014). According to the new market ideas applied to the legal profession, the outsourced lawyer has to be client-oriented and adapt to their needs; they must adapt to the speed of their client's business, incorporate management and business knowledge, keep up with technological advances and include English as a working language. When educating lawyers, social skills must also be fostered, as well as skills in managing teams, subjects (projects) and clients. The demands placed on the early years in the profession have increased, too. The idea of a professional or local partner has been losing ground and there have been changes in the systems of partnership in terms of sharing risks and increasing capitalisation. Moreno-Meyerhoff (2014) say that the most egalitarian lockstep-style systems are shifting towards one where everyone looks out for themselves, each person's income becoming more dependent on what they contribute and generate themselves as individuals. Everyone has to make an effort. In recent years, for example, the term 'uberisation' has spread into the legal sector (Skapinker, 2016).

\section{Working as a lawyer today in Spain: the main sources of precariousness}

During the second half of the twentieth century, professional lawyers in Spain were a social sector identified with professional middle classes on the rise. Their knowledge of a strategic sector in the social system, namely the legal structure, their solid corporate structure and their recognised professional status all led to the lawyers' profession becoming associated with social promotion and the gradual accumulation of symbolic and economic power. Related to the government elites for centuries, the profession of lawyer adapted and changed with the transformations of the state in the second half of the twentieth century, as we have just mentioned. The growing complexity of the legal framework in that time progressively created a profession very much in demand, establishing corporate and educational structures with a great many university places available and extending its social base. This trend made it possible not only for people to enter the profession of lawyer via generational change within the old middle classes, 
but also for other factions of the middle classes without a family tradition of lawyers or university studies among the parents to also be able to get their children into the profession. The tendency gradually progressed throughout the second half of the twentieth century, but underwent very significant changes in the 1990s that ended up transforming the professional structure for lawyers and creating an atmosphere of need for change and modernisation in the profession. The crisis of 2007 only aggravated this atmosphere and complicated the general situation, above all in the offices and among professionals in weaker posts. Such jobs have been doubly hit by the cutbacks and changes in legislation, which have increased legal fees for potential clients and cut back on funding for duty solicitors.

The prominent aspects of the crisis are seen in a scarcity of clients and pressure on fees charged. Lower demand has led to intense competition among the ample supply of lawyers. This in turn has led to them lowering their fees, added to delays in payments and clients demanding to be able to pay in instalments. This race towards lower fees has forced many members of the profession to adapt, accepting badly-paid outsourced work or offering low-cost services with fees unheard of before among lawyers. Those dropping out of the profession are not an exception. An evidence of this is the high percentage of replies about difficulties in the world of lawyers. In the last survey by the Consortium of Spanish Bar Associations (Consejo General de la Abogacía Española, 2015), 85 per cent of the lawyers working said that many colleagues are facing serious economic difficulties. The percentage of those who believe that the profession of lawyers is in a bad or very bad situation comes to 51 per cent. This is an increase of 20 per cent compared to the previous survey in 2008. Precariousness is a very real situation in the profession.

In the interviews, which we shall analyse in the next section, we have been able to distinguish the different ways in which precariousness seeps into the life of lawyers. As a general observation, it should be noted that the precariousness is linked to a change in the traditional social and demographic structure caused by growth in the number of young people with a university degree, mainly women and many from working-class families. This creates difficulties to enter the job market in the profession, and precarious working conditions. Moreover, the precariousness is linked to new entrepreneurial styles and new ways of understanding the profession, which are difficult for the most disadvantaged people in the profession to adapt to. This precariousness has also been aggravated by the tough economic situation in today's climate of economic crisis.

\section{The many dimensions of precariousness}

The purpose of our study has been to discover how liberal professionals perceive and interpret the changes they have faced in their professional lives, and by extension in their lives in general. The study has therefore been fundamentally qualitative. It was based on 32 in-depth interviews with lawyers, architects and journalists and an analysis of their practices and experiences of the crisis and current professional changes. The interviews, carried out in theValencian Community region, address the interviewees' past professional career, current handling of uncertainty and precariousness, and possible training and labour strategies. The sample includes professionals from the three aforementioned professions of intermediate ages (29-51 years), which has enabled us to include the youngest age groups in an initial career stage at a time of 
life marked by important decisions. At the other end of the range there are more established professionals, who even so have found themselves destabilised by the crisis and by the new aspects of job uncertainty. We contacted somebody in each of the professional sectors, who then contacted others in their sector in a snowball effect. The interviews were carried out preferably in a lawyers' office. They were recorded and transcribed, then analysed according to the subject matter. In this article, we focused on the interviews carried out with lawyers: a total of 12 professionals made up of eight women and four men.

The precariousness perceived and experienced by the lawyers interviewed has many dimensions. We based our study on a definition of job precariousness that accounts for different aspects of the job market, specifically: employment conditions (type of job contract, instability); working conditions (timetables, shifts and so on); insufficient salary; deficient social protection for workers (influence of precariousness on future benefits); and as regards assurance of trade union representation. Broader definitions of precariousness in specific studies on the matter (Standing, 2011) mainly include the aspects we have just mentioned, though also include others such as precariousness in access to training within the job post, which are not a priority in our study. In addition, it should be mentioned that although job precariousness is rising in the job market, it is also gradually spreading to other facets of life, leading to precariousness in life in general (Butler, 2009; Lorey, 2014). In this sense, the ever-more blurred boundaries between work and personal life coupled with the uncertainty in taking decisions throughout one's life are leading to an increasing impact of job precariousness on people's social life. These aspects have often been expressed in the interviews carried out in our study.

\section{Income and working conditions: lack of pay and intensification of work}

Interviewees expressed precariousness in terms of their income and working conditions, but this translates immediately into great uncertainty for them as regards their living conditions and careers. As expected, age and gender are factors that exacerbate this. Below, we shall see some of the main dimensions.

Income is a constant worry for most of the interviewees. Although the traditional image of the lawyers' profession tends to be considered a well-paid occupation, on the contrary lawyers' experiences demonstrate endless big and small economic worries that beleaguer their working life. Generally, the scarcity of clients and pressure on fees are mentioned, with the added burden of the economic crisis. The drop in demand for their services has led to intense competition among an ever-increasing supply of lawyers. This has consequences on the quality of the work. The following quote explains some of this economic damage:

Being a lawyer today is expensive. We have a lot of costs and the income has fallen sharply. In recent years it's been... The crisis has struck this profession head-on. There are a lot of people who shut down their offices; a lot of people have had to change habits or go home to work while others have left the profession. A lot of people have left it. There are a lot of people who are starting out and they're very keen, so what's happening? Well, they are re-orientating the market. For example, they are offering divorces at 50 per cent or $€ 200$, which is...I saw one for 
$€ 50$ and it says: 'All included'. All included supposedly means VAT; the court representative also charges their fees. So you say: 'What's all this?'. Logically, they're doing a very poor job, and then those people come to you to modify it or change part of the regulatory agreement they've made... Then you have to go to court again, sort it out again, and start again. (E3. Woman; 48 years old)

There are many testimonies that indicate insecurity the client payments, with a very significant volume of non-payments and very lengthy times in getting paid for their services. This insecurity is common to all the lawyers interviewed in addition to the younger ones who are in an even more seriously vulnerable situation. Late payment generates great irregularity and insecurity in their fragile economic conditions, faced with the expenditure they must bear at the beginning of their careers. It is important to point out that they must cover some high costs to get by in their profession. For example, the first registration in bar associations to work as a lawyer costs around $€ 700 .^{1}$ This is in addition to other amounts such as lawyers' health insurance and special social security contributions for their kind of self-employment, office rent and other overheads such as updating computer hardware and software to tackle the expected renewal of the sector or to pay for the use of platforms like LexNET, which is a new compulsory online service provided by the judicial system to handle information and documents. The need for training as regards the legislative changes also implies a considerable outlay which they must meet. All of this makes them less competitive compared to older, more experienced lawyers. Those who work in small offices are also less competitive than those in big offices where the costs are shared among many workers.

One professional area that has accumulated great precariousness is the work by lawyers in free justice known as duty lawyers. This is a practice that holds considerable social and professional prestige in terms of the lawyers' ethical commitment and their social role, but at the same time there is a significant source of precariousness for those who take it on. The latest report from the Free Justice Observatory (Abogacía Española-La Ley, 2016) states the volume of work implied by such duty work by lawyers and the problems it currently faces. In 2015, 46,800 lawyers registered in the duty lawyer service worked on 1,745,000 matters and enquiries in the 905,000 cases presented in the courts and bar associations that bring justice to the most disadvantaged social groups. This means that an impressive 30 per cent of all lawyers are involved in duty tasks. Their average age is 41 years, indicating a large number of young people. They deal with an average of 20 cases a year and receive about $€ 4,000$ in income on average. It is estimated that the income per hour comes to $€ 4$ to $€ 6$ depending on the region where the proceedings take place. These are not high figures; far from it. In fact, those interviewed who do duty work repeatedly mention the paltry income it gives them. Furthermore, not only is the income low but also it has not been raised much; it is paid with great delays and moreover does not include the expenditure that lawyers have to bear such as travel or photocopying of the necessary material to draw up their defence. In the case of Valencia, this income was lowered sharply by up to 60 per cent as a result of the political handling of the economic crisis. In general, in Spain, spending on this sector was cut by 15 per cent from 2010 to 2013 , even though the problems linked to the crisis in recent years have increased the need for free justice. 
The matter of work as a public duty lawyer drains you...A mutually agreed divorce process may be worth $€ 250$...But it's a job where you have to deal with the client, you have to travel, you have to make copies, you have to dedicate time. (E1, Woman; 44 years old)

This situation of greater precariousness in lawyers' duty work has driven lawyers (a social group that is not very inclined to protest in public) to carry out protests: work-to-rules, demonstrations at the doors of the courts and sit-ins to demand changes to improve their situation. For specialists, after 20 years of the law in force that regulates free justice, profound transformations are needed: to introduce quality control for the service, set up ongoing training programmes, broaden the coverage with new specialisations, update the standards or ensure that the service is carried out by lawyers and not less qualified people, along with other measures (Abogacía Española-La Ley, 2016).

Most of those who we interviewed work in the duty service. It is a voluntary activity for which they need to register and meet certain professional requirements such as proof of at least three years working as a lawyer. The experience described in the following passage is often repeated by lawyers, who consider that the relationship between the income received and the time dedicated is completely disproportional:

That serious case paid four hundred [euros], but I spent eight days of trial with three shifts, plus another twenty or so phone transcriptions. You have to read it all thoroughly, prepare for the trial, eight days in the court; there will be lawyers that have charged their clients $€ 60,000$... And me, four hundred, and my other duty colleagues another four hundred, for the whole trial which of course lasted months and months and months. You go to all the statements, prepare well, then you do the trial, eight days of trial, that's a great deal of work. (E3, Woman; 48 years old)

In addition to the economic conditions, the precariousness $i$ also arises in terms of working conditions, both in the duty work and in private law work. First, the working hours are spread out throughout the day (even at night), throughout the week with no consideration of differences between weekends or holidays. These hours depend on the deadlines to handle the case ('the lawyer's hours are the deadline' (E5, man, 34 years old)). Therefore, the organisation of their time depends on other parties involved in the working process: clients, government administration, courts, and so on. This makes it very difficult to establish minimum planning in their work. Although it is true that this is a clearly worrying aspect that generates anxiety among those interviewed, it is also seen as a chance for flexibility since they feel that they decide their own timetables. This paradox of time clashes with the material circumstances in which work imposes on their life and leaves little margin for freedom with the often false hope of many self-employed people that they may set their own hours and attend to matters in their family and personal life. This paradox continues to set a trap regarding time, generating an intensification of work that causes more precariousness:

There are times you do it because there's no choice. You don't depend on yourself, you depend on the court. If it asks you for something in three 
days, you have to prepare the text no matter if it's raining, sunny, if there's a communion, an important day; it's all the same. If you have a deadline, you have a deadline and you have to do it. And if you ask the client for the documents and they don't give them to you until almost the last day, well, you have no choice. One often works at the weekend, even at night, because you get the documents at the eleventh hour and without them you can't draw up a text explaining the situation, so sometimes you have to stay up till three in the morning to meet the deadline, because there's no other way. (E7, Woman; 35 years old)

Second, precariousness can be seen in the variety of tasks needed in the lawyers' profession when one is self-employed and working in one's own office. When the work is done in small towns all local contexts, the lawyers have to master a variety of specialisations and knowledge. This versatility is necessary to open up markets or maintain the trust of the usual clients who demand it. When a long-term client appears in the office, the priority is to solve the problem they pose. The professional relationship with the client does not take into account specialisations, they explained to us. Moreover, as can be seen in the following extract, the interviewee points out that the versatility does not only spring from these dividing lines between specialisations, but also from the economic needs to do all of the tasks involved in their occupation, even those that go beyond it:

Specifically, my work is based on going to courts, police stations and so on. It is pure, hard office work, attending to clients, a lot of administrative work, from receiving an e-mail to printing papers, and making heaven knows how many calls. For example, I don't have a secretary, in other words I'm the one who does everything. (E9, Woman; 42 years old)

\section{The entrepreneurial lawyer: increasing uncertainty}

To round off this list of sources of precariousness, we should note the new demands imposed by the model of the entrepreneurial lawyer that is ever more present. As we have seen in the theoretical section, today's lawyers are advised to continually take care of their profile as an entrepreneur, managing their office as a service, diversifying the product, taking quality seriously, knowing how to sell themselves, gaining a reputation and being appreciated. As a result, more than a few interviewees expressed the need to do marketing tasks and seek new clients. Although most state that they do not identify very much with that model of professional, it can be seen that, above all, the youngest interviewees assume the need to carry out specific activities that may open up new markets. As examples of this spreading spirit of the entrepreneurs who seek to stand out and know how to sell themselves, one could mention their presence in the social networks, maintaining a website, blog or a Facebook profile. They also use ads in the general or specialised press.

How do you go about the commercial work? How do you get clients? On the radio.

And is that working for you? Yes. The radio, sure...In bygone times there was an unwritten rule that said that lawyers couldn't advertise... 
Was that a decision by the young ones in the office? I decided that myself, by royal decree, yes, yes. And then the website. Now there's an app called elabogado.com, that when people have a query they go there. Of course, you go to the Internet, these days you go to the Internet for everything, and I answer queries via the Internet... and via Facebook too: you post some interesting snippets that don't tire or bore them, but by posting interesting snippets that people can... (E9, Woman; 29 years old)

The entrepreneurial discourse easily penetrates into the group of lawyers that we have studied due to their professional situation as independent, self-employed workers. In the most current entrepreneurial-based ideologies of labour, the model of the independent worker and the micro-entrepreneur is a person attributed with an innovative nature and one who breaks away from the well-trodden paths of labour. Contrary to this archetypal innovator, the situation we have found among the selfemployed lawyers interviewed is that they are particularly exposed to uncertainty and economic fluctuations.

As for social protection, self-employment in Spain is characteristic for having little coverage in terms of economic and social benefits (Célérier et al, 2016). As has been noted, the main regulations applied to them are in the Autonomous Workers' Statute of 2007, which does not fully clarify this grey area in which self-employed work is done, since it falls in the dividing line between the company and salaried work (Riesco, 2016). For example, coverage for situations such as retirement is lower for self-employed people, who get an average pension considerably lower than employees $(€ 1,200$ a month compared to $€ 780$ for self-employed people). Other kinds of coverage, such as for illness, are excluded from the obligatory contributions. They are voluntary, so that in many cases self-employed people do not have this protection against the risks arising from their professional activity.

To sum up, self-employed workers are in a category that works on the margins of the labour market. They are formally considered as companies, open to situations that may lead to great vulnerability and precariousness, as indicated by their low contributions and insufficient coverage. This mixture of exposure to risk and lack of a safety net means that self-employed people are workers that may easily be subject to self-exploitation in addition to living with considerably high levels of uncertainty. The myth of the entrepreneurial self-employed person is dispelled when the real, poor conditions in which self-employed people work are revealed. Those with high salaries who fit the entrepreneurial style are a chosen few. However, for most the income is low and the inequalities in salary continue to spread with the justification of the idea that talent marks the differences and each person has a different level of talent and reputation. The following quote that ends this section gives details of this contrast and the precarious experiences of the autonomous lawyer.

That takes a lot because of course you have to save someone's skin and all the rest so that at the end of the month you get a wage and are able to survive. Now, for example, I am eight months' pregnant and people say, 'Are you taking leave?' And I say: 'What leave? Self-employed people don't get leave.' And they say: 'How are you going to organise yourself when the child comes?' And I say: 'Well, look, for the first month I'll be with him because I should, and after that I will get back bit by bit, or I 
have the option of working from home.' Sometimes you find that working for somebody else is much better than being self-employed. (E8, Woman; 38 years old)

In this extract there is an aspect that is common in the interviews carried out: the burden of gender in building lawyers' careers. The process of feminisation seen in Spain over the last 20 years has been accompanied by persistent discriminations and ingrained stereotypes from our recent past in which there was absolute masculine predominance not so long ago (Blanco, 2009; Codina and Pestana, 2013; Calvo, 2017).This range of discrimination is seen in the problems in conciliating home life and in the demands of a model of work involving intense dedication that favours male professionals and does not fall in step with family care that is mostly borne by women.

It should be noted that the force of the factors generating precariousness that we have analysed does not completely stop the responses and strategies of the lawyers interviewed. Nevertheless, these replies show a very limited range and scope of action. They talk about the short term and short distances of nearby relationships (family, friends and work colleagues). The lawyers interviewed manage to avoid the increasing precariousness that affects them, designing strategies that enable them to mitigate its harshest effects. Notable strategies include sharing costs when renting offices where they carry out their profession, mutually passing on clients and diminishing the dominant competitiveness and the individualistic nature of the self-employed work logic. Given the family nature of Spanish welfare (Naldini, 2003), support from one's own family or in-laws is a notable contribution that helps to alleviate the precariousness and, in some cases, to be able to organise one's work time. The latter case is observed above all in cases where female lawyers can maintain their unstable, low-paid work activity at the expense of relying on their husband's income. Parents can also serve the same purpose in supporting the youngest lawyers, who practically 'pay' to work and gain experience. Furthermore, this makes it clear that there is little confidence in the existing public social protection mechanisms which, as we have indicated, are very primary.

Together with very basic group collaboration strategies, there are individual strategies that stand out in their discourses which are fundamental in shaping their pace of life and their expectations backed by effort, for example by keeping expenditure down and a significant austerity in their lifestyles, encouraging saving as a means of anticipating future precariousness. This is a common practice that provides a small margin for decision-making within the context of an extreme, suffocating precariousness. Moreover, the individual strategies also involve duplicating their capacity for work and keeping up to date to respond to the demands of a market that is generating great unease among them given its recent transformation. This means entering the ambivalent terrain of self-exploitation that sometimes looks like a positive resource in the hope of better times, but which may lead into a spiral that makes the precariousness and overwork more acute. But above all, all of the interviews call on the vocation to keep alive a job which, though it does not give big material compensation, does offer a symbolic compensation and a strong sense of ethics and commitment to the job. Doing a good job, meeting deadlines, not sleeping, working weekends and savouring a job on its completion all seem to compensate for the precariousness in income and life's uncertainty. 
Yes, I've chosen the right job; it's clear. When you win in a complicated matter, it's clear.Yes, the satisfaction one feels...And then you call your friends and tell them: 'Do you remember that matter I told you about? They found I was right.' (E7, Woman; 35 years old)

Rosalind Gill (2011) and Remedios Zafra (2017) put forward the role of 'enthusiasm' to analyse the situations of creative and knowledge-based jobs in which young people work: badly paid jobs immersed in precariousness and uncertainty, at most acknowledged symbolically. In the case of the lawyers interviewed, enthusiasm also enables them to put up with all kinds of precariousness in order to stay in their chosen profession as their vocation and thus do a job that is considered to be creative until they attain stability and the precariousness ceases. This future promise does not often materialise, but it always entails acceptance of a model of competitiveness that breaks group bonds and individualises people's life courses. This enthusiasm enables the lawyers interviewed to attempt to palliate the perception of insecurity and uncertainty that is generated by the conditions in which they are carrying out their profession. Furthermore, these conditions are unexpected.

\section{Conclusions}

Throughout this article, light has been cast on the connections between the changing professional model of the lawyers' job over the past three decades and the emergence of precarious situations in the most vulnerable sectors of the profession. The depth and variety of the changes have been analysed in the first sections of the text, where we have seen that the combination of structural and circumstantial factors have restructured the profession and altered the context of the traditional profession for lawyers. In Spain, a particular combination of these factors has led lawyers into a weaker structural position (above all, young people and women) to shoulder the burden of precarious situations.

The precariousness described by the lawyers interviewed is seen to have many dimensions. It is seen in the income and in the working conditions, but also ends up completely seeping into their living conditions. This leads to professional careers marked by extreme uncertainty. The main sources of their precariousness are seen in the constant worry as regards income, with low remunerations that have worsened in the last ten years. The clients have dwindled and the competition among a very large supply of lawyers has obliged them to reduce their fees, accept low-income outsourced work and to offer low-cost services. In addition to the economic conditions, precariousness is also seen in the working conditions. First, it is seen in the hours and the time dedicated, which generates a precarious intensification of the work. The spheres of work and personal life overlap, increasing psychosocial risks. Precariousness can also be seen in the variety of tasks characteristic of the lawyers' profession when one is self-employed working in one's own office. As regards this aspect, the new demands imposed by the model of the entrepreneurial lawyer add subtle forms of precariousness caused by the need to redirect their work in order to manage the office as a service, in which priority must be given to diversification of the product, quality and the logic of customer service. The entire entrepreneurial style of work involving earning a reputation, gaining visibility, creating a marketing 
strategy for oneself, all generates suffering due to a model that they often experience as an imposition.

The research done makes it clear to us that there has been a transformation in the occupation of the lawyer in Spain. It is a change that has been brewing in recent decades and which the last economic crisis has accelerated and deepened. Political decisions taken as regards this transformation (legislative changes, reforms in free justice, a growing hegemonic discourse of entrepreneurship, and above all the weakness of self-employed workers' social protection) have created a stark future of precariousness for lawyers. It is a horizon that they are facing only with their individual and family resources, taking on board the very same entrepreneurial discourse that is creating precariousness for them.

\section{Funding}

This work was supported by theValencia Department of Education, Research, Culture and Sport (Conselleria d'Educació, Investigació, Cultura i Esport de la Generalitat Valenciana) (R\&D Projects for emerging research groups, GV/2015/055).

The Authors declare that there is no conflict of interest.

\section{Note}

${ }^{1}$ The fee for the first time that they register as active lawyers in theValencia Bar Association, ICAV (Ilustre Colegio de Abogados de Valencia, www.icav.es). This fee includes legal liability insurance. The amount may vary according to the association and geographical area where they register, but most of the lawyers interviewed were registered with ICAV.

\section{References}

Abogacía Española-La Ley, 2016, Justicia Gratuita. X Informe del Observatorio de la Justicia Gratuita. Estadística Completa 2011-2015, Madrid:Wolters Kluwer

Atkinson, A, Brandolini, A, 2013, ¿Desaparece la clase media en Occidente?: una advertencia, Vanguardia Dossier 47, 38-44

Bauman, Z, 2006, Liquid Times: Living in an Age of Uncertainty, Cambridge: Polity

Blanco, T, 2009, La feminización de la Justicia: una conquista aún a medio camino, Abogados, Revista del Consejo General de la Abogacía Española 57, 6-12

Böck, H, 2015, O das un abrazo a 'New Law', o piensa en jubilarte, Diario La Ley, 8628, Sección Tribuna, 20 Octubre

Bologna, S, 2006, Nuevas formas de trabajo y clases medias en la sociedad postindustrial, Duoda, Revista d'estudis Feministes 30, 59-74

Bologna, S, Fumagalli, A, 1997, Il lavoro Autonomo di Seconda Generazione. Scenari del Postfordismo in Italia, Milano: Feltrinelli

Butler, J, 2009 Frames of War: When is Life Grievable? London New York:Verso

Butler,T, Savage, M (ed), 1995, Social Change and The Middle Classes, London: UCL Press

Calvo, P, 2017, La mujer en la abogacía, evolución de la desigualdad profesional, www.abogacia.es/2017/01/26/la-mujer-en-la-abogacia-evolucion-de-ladesigualdad-profesional/

Cano, E, 1998, La investigació sobre la precarietat laboral al País Valencià, Arxius de Sociologia 2, 167-178

Castel, R, 2010, El ascenso de las Incertidumbres. Trabajo, Protecciones, Estatuto del Individuo, Buenos Aires: FCE 
Castells, M, 2015, Sociedades polarizadas, Sin Permiso, 17 October, www.sinpermiso. info/textos/sociedades-polarizadas

Célérier, S, Riesco,A, Rolle, P, 2016, Trabajo autónomo y transformación del salariado: las reformas española y francesa, Cuadernos de Relaciones Laborales 35-2, 393-414

Chauvel, L, Hartung, A, 2016, Malaise in the Western middle classes, World Social Science Report 2016, Paris: UNESCO-ISSC

Codina, N, Pestana, JV, 2013, Cambios, (des)igualdades y día a día del profesional de la abogacía, Papers 2013, 98/3, 471-487

Consejo General de la Abogacía Española, 2015, Barómetro Interno del Consejo General de la Abogacía Española 2015, Madrid: CGAE

Damon, J, 2014, La classe Moyenne Américaine en Voie d'effritement, Paris: Fondapol

Fourquet, J, Mergier, A, Peugny, C, 2013, Le Grand Malaise, Enquête sur les Classes Moyennes, Paris: Foundation Jean Jaures

Frank, R, 2007, Falling Behind: How Rising Inequality Harms the Middle Class, Berkeley, CA: University of California Press

Garrido Navarro, MM, 2015, La Abogacía en el siglo XXI, Diario La Ley, 8625, Sección Tribuna, 15 Octubre

Gill, R, 2011, Life is a pitch: Managing the self in new media work: Managing media work, in M Deuze (ed) Managing media work (pp 249-262), Thousand Oaks, CA: Sage

Hernández, E, 2014, El fin de la Clase Media, Madrid: Clave Intelectual

Jessop, B, 2016, The State. Past, Present, Future, Cambridge: Polity

Laval, C, Dardot, P, 2013, La Nueva Razón del Mundo: Ensayo Sobre la Sociedad Neoliberal, Barcelona: Gedisa

Lazzarato, M, 2013, La Fabrica del Hombre Endeudado. Ensayo Sobre la Condición Neoliberal, Buenos Aires: Amorrortu

Lorey, I, 2014, State of Insecurity, London:Verso

Milanovic, B, 2016, Global inequality: A New Approach for the Age of Globalization, Cambridge, MA: Harvard University Press

Moreno-Meyerhoff, J, 2014, El abogado de éxito, Diario La Ley, 8403, Sección Tribuna, 21 Octubre

Naldini, M, 2003, The Family in the Mediterranean Welfare States, London: Frank Cass

Riesco, A, 2016, Trabajo, independencia y subordinación. La regulación del trabajo autónomo en España, Revista Internacional de Sociología 74-1, 2-26

Sánchez Fernández, LJ, 2014, Emprendedores jurídicos: la huida hacia delante, Diario La Ley, 8403, Sección Tribuna, 21 Octubre

Santos, A, Muñoz, D, 2017, Más allá de la precariedad laboral. Los nuevos rasgos de la precariedad juvenil, Gaceta Sindical 29, 235-252

Sennett, R, 1998, The Corrosion of Character: The Personal Consequences of work in the New Capitalism, New York: WW Norton \& Company

Skapinker, M, 2016, Technology: Breaking the law, Financial Times, 11 April, www. ft.com/content/c3a9347e-fdb4-11e5-b5f5-070dca6d0a0d

Standing, G, 2011, The Precariat. The New Dangerous Class, London: Bloomsbury

Streeck, W, 2013, The crisis in context: Democratic capitalism and its contradictions, in A Schäfer,W Streeck (eds) Politics in the Age of Austerity (pp 262-285), Cambridge: Polity Press

Susskind, R, 2008, The End of Lawyers? Rethinking the Nature of Legal Services, Oxford: Oxford University Press

Susskind, R, 2013, Tomorrow's Lawyers, Oxford: Oxford University Press 
Therborn, G, 2015, The Killing Fields of Inequality, Cambridge: Polity Zafra, R, 2017, El Entusiasmo. Precariedad y Trabajo Creativo en la era Digital, Barcelona: Anagrama 